\title{
The 1975-76 Federal Deficits and the Credit Market
}

\author{
RICHARD W. LANG
}

\begin{abstract}
ry
HE possible effects on credit markets of the fiscal 1975 and 1976 U.S. Government deficits were of considerable concern in late 1974 and early 1975. Projections of these deficits ran from $\$ 50$ to $\$ 80$ billion or more. A number of analysts outlined certain conditions under which the financing of such large deficits by Treasury borrowing would have adverse effects on credit markets, pushing short-term interest rates into the double-digit range again and crowding out private borrowing for capital formation. If these conditions developed, it was suggested that the Federal Reserve might attempt to keep interest rates from rising by increasing its rate of purchase of Government securities. As a result, there would be a large increase in the growth of the money stock, which eventually would lead to a new inflationary spiral that would push interest rates higher due to increased inflationary expectations. ${ }^{1}$
\end{abstract}

The concem for credit markets was based on the assumption that the increased Government demand for credit wonld overwhelm any decrease in the private demand for credit as well as any mcrease in the supply of credit. Other analysts maintained that although Government borrowing would increase, private borrowing would decrease substantially duning the recession. This decrease in the private demand for funds was expected to largely offet the increased Government demand, with the result that the larger deficits would have little effect on either interest rates or the total quantity of credit."

The deficits in fiscal 1975 and 1976 were $\$ 43.6$ billion and $\$ 65.6$ billion, respectively, while the largest deficit in the previous ten fiscal years was $\$ 25.2$ billion (see Table I)." Thus, relative to recent historical

This possibilty was expressed in this Review in a number of different articles. See, for example, Damyl R. Francis, "How and Why Fiscal Actions Matter to a Monetarist," this Revicu (May 1974), p. 7; W. Philip Gramm, "Intation: Its Cause and Cure" this Revew (February 1975), pp. 5-6; or Susan R. Roesch, "The Monetary-Eiseal Mix Threngh Mid-1976," this Review (Angust 1975), pp. 2-7.

"This point of view was clearly expressed by James L. Pierce, "Hiterest Rates and Their Prospect in the Recovery," Brookirgs Popets on Economic Activity $(1: 1975)$, pp. $89-112$.

"Using the minfied budget data as reporied in the Federal Reserve Bulletin.

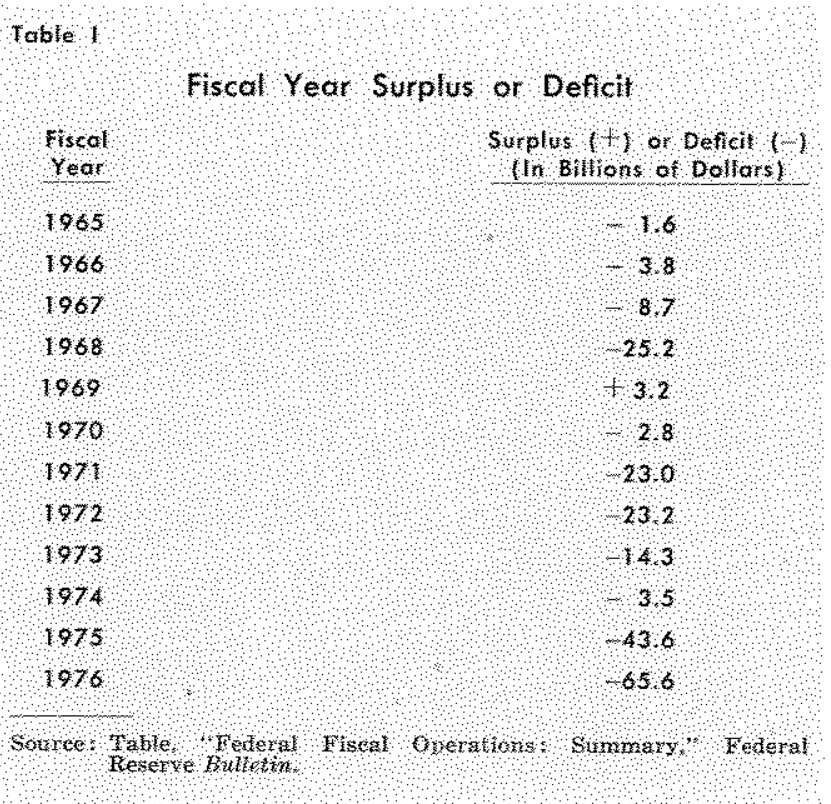

standards the deficits in 1975 and 1976 were indeed large, and it is not surprising that they generated considerable concem. But what happened to credit markets and interest rates during this period?

\section{整A A H

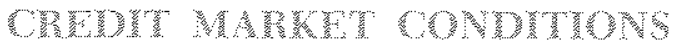

Credit market conditions can be discussed in terns of a simple supply and demand framework which lumps all credit markets together. ${ }^{ \pm}$The quantiry of credit and the price of credit (the market interest rate) are determined by the supply of and the demand for credit. The total demand for credit consists of a private demand plus a Goverment demand.

An increase in the Federal deficit which is financed by increased Govermment borrowing results in an increase in the Government's demand for credit and, hence, an increase in the total demand for credit above what it would be in the absence of the increased Government borrowing. The extent to which the increased Federal deficit increases the total

the discussion in this paper is only in tems of the nomiral supply and demand for credit and nominal rates of interest. 
demand for credit depends in large part on whether the deficit is predominantly due to "active" or "passive" elements in the budget. ${ }^{5}$ Discretionary changes in Federal expenditures and taxes which result from Congressional or Executive actions are "active" elements in the budget. Nondiscretionary, or automatic, changes in Federal expenditures or taxes which result from changes in the level of economic activity are "passive" elements in the budget. A Federal deficit which is primarily the result of active elements in the budget will tend to produce a larger increase in the total demand for credit than if the deficit were primarily due to passice elements. This tendency reflects the fact that credit fnances economic activity. If the budget deficit is the result of passive elements, the decline in economic activity which leads to the increased deficit is also generally accompanied by a decline in the private demand for credit.

Given an increase in the total demand for credit from an increased Government deficit, regardless of whether the deficit is active or passive, the market interest rate increases as potential borrowers bid for the avalable credit. As a result, the quantity of credit supplied increases as suppliers of credit are induced to increase their lending by the rise in interest rates. Since Federal Govermment borrowing is relatively insensitive to changes in the cost of borrowing, the main effect of a rise in the market interest rate is on private sector borrowing. If other factors are unchanged, private borrowers will want to borrow a smaller quantity of credit at this higher interest rate. Since the total quantity of credit supplied is larger, this implies that the proportion of credit going to the Govemment is larger. The resulting absolute decrease in the amonnt of private sector credit is one illustration of the argument that Government borrowing "crowds out" private borrowing."

This simplifed analysis describes the underlying rationale for some of the warnings expressed in 197475 about higher interest rates and private bor rowing. It was maintained that if the Govemment increased its debt by $\$ 50$ to $\$ 100$ billion in order to

\footnotetext{
"For a detailed hiscussion of "active" and "passive" budget deficits, see Keith M. Carlson, "Large Federal Budget Deffcits: Perspectives and Prospects," this Revict (October 1976), pp. 2-7.

"For a detalled discussion of "crowding our", see J. Kurt Dew, "The Capital Market Crowding Out Problem in Perspective" Fecteral Reserve Bank of San $\mathrm{F}^{\mathrm{T}}$ rancisco Economic Revew (December 1975), m. 36-42; Foger W. Spencer and Willam $P$. Yohe, "The 'Crowding Out of Brivate Expenditures by Fiscal Policy Actions," this Review (October 1970), pp. 12-24; and Keith M. Carlson and Roger W. Spencer, "Crowding Out and Ifs Crities," this Review (December 1975), pp. $2-17$.
}

finance the large projected deficits, with other factors unchanged, market interest rates would rise. Furthermore, it was claimed that if the Federal Reserve purchased a large proportion of the increased debt in an attempt to prevent this increase in interest rates, higher expected rates of inflation wonld result. This, in tum, would lead to higher interest rates. The above analysis also implied that the nominal quantity of credit outstanding would increase.

The above outlook for the credit market depended heavily on the assumption that there would not be a substantial decrease in the private demand for credit. Some analysts, however, maintained that the recession would induce much lower private investment because of higher excess capacity, and that the private demand for credit would therefore decrease substantially during fiscal 1975. Private borrowing would be lower primarily as a result of a decline in the private demand for credit and not as a result of a rise in market interest rates. This decrease in private demand, according to proponents of this view, was expected to offset, although not totally, the increase in the Government's demand for funds. ${ }^{7}$

This point of view generally maintained that the credit market would be basically unaffected, in terms of price and total quantity, by the large increase in Government borrowing. As a result of the changes in private and Government demands, the distribution of total credit would change, but interest rates would not be substantially increased and the quantity of credit outstanding would be increased only slightly. Of course, in the absence of the Government's increased borrowing, the expected decrease in private demand wonld have implied even lower interest rates in 1975-76, according to this view.

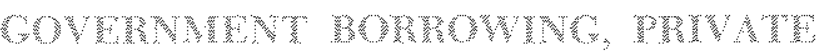

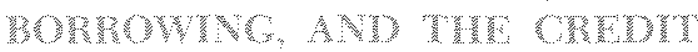

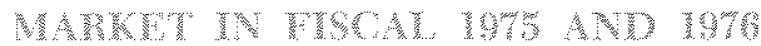

In 1975 and 1976, short-term interest rates did not rise above their mid-1974 peaks, but instead tended to decline. Although short-term rates rose in mid-1975 and again in mid-1976 (see Chart 1), these upward movements were not sustained and were not as severe as some analysts had expected. In mid-1975, the upward movement in short-term rates peaked at rates below 7 percent, and in mid-1976 they peaked at

\footnotetext{
TPierce estimated that Govemment borrowing in calendar year 1975 would increase by $\$ 80$ billim whle borrowing by other nonfmancial sectors wonld decrease by $\$ 72$ billion. See Pierce, "Interest Rates," pp. 106-8.
} 


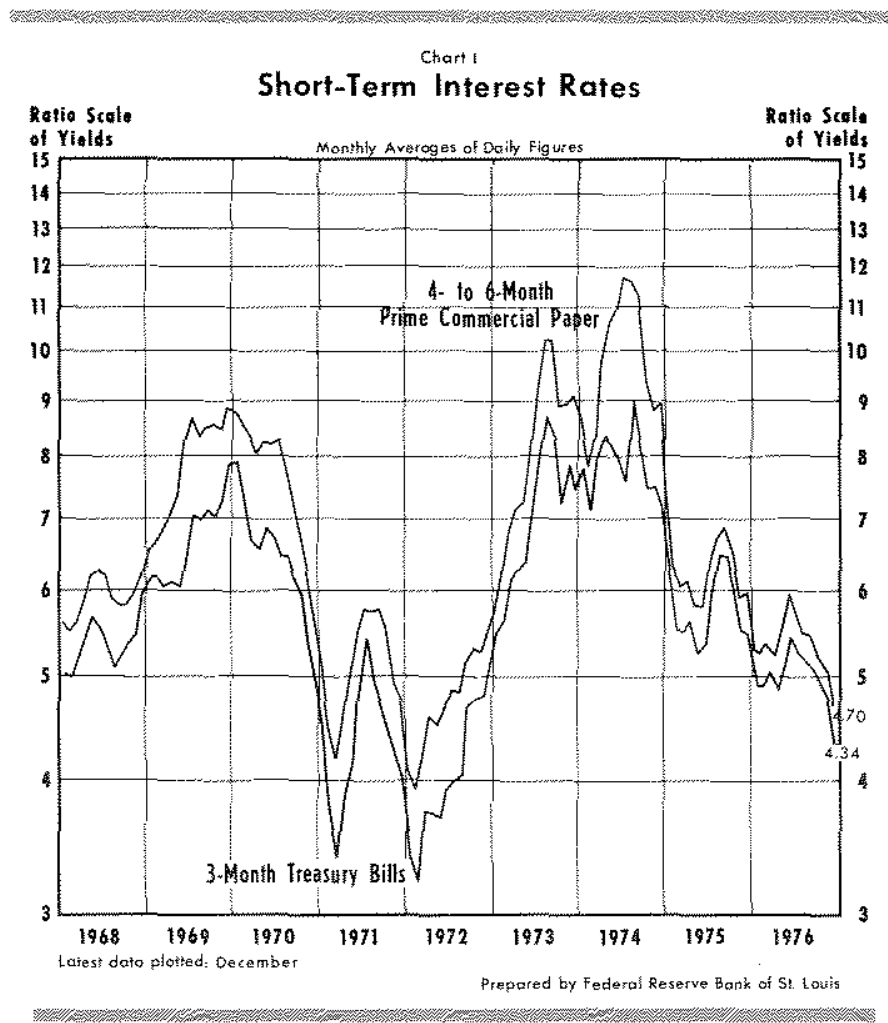

rates below 6 percent. In both cases, short-term rates were well below the 1974 peaks of about 12 percent for four- to six-month commercial paper and about 9 percent for three-month Treasury bills. Long-term interest rates also generally declined from mid-1974 levels, although not as dramatically or consistently as short-term rates (see Chart II).

The funds raised by all nonfuancial sectors in fiscal 1975 were about $\$ 8$ billion lower than in fiscal 1974 (see Table II). In order for both interest rates and the total amount of new credit to be lower in fiscal 1975 than in mid 1974 , the total demand for credit must have decreased in 1975. Since Government demand for credit increased in fiscal 1975, private demand must have decreased substantially. ${ }^{8}$ A decrease in the demand for credit by the private sector would have to more than offset the increased Govemment de mand in order for the total demand for credit to decline.

While the Federal Government raised $\$ 50.7$ billion in fiscal 1975, compared with 83.3 billion in iseal 1974 , all other nonfinancial sectors raised $\$ 132.6$ billion a decrease of $\$ 55.5$ billion from the fiscal 1974 level.

SSusan R. Foesch and Keitl M. Carlson both noted this. See Roesch "The Monetary-Fiscal Mix" p. 2 ; and Carlson,

"Large Federal Budget Deficits," p.6. The fall in private de. mand was also discussed by $\mathrm{R}$, Alton Gibert, "Bank Financing of the Recovery," this Review (July 1976), pp. $2-9$.

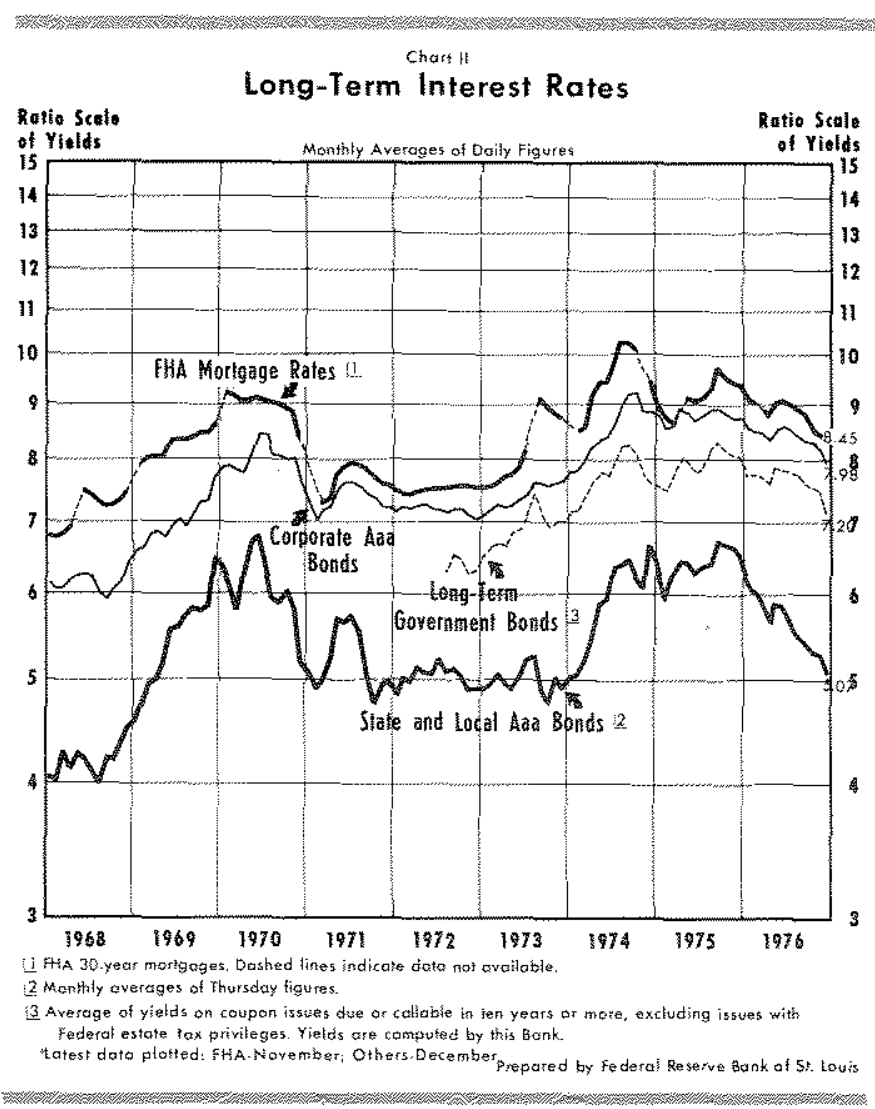

This was the largest year-to-year decrease in the amount of funds going to the private nonfinancial sector in the post-World War II period.

Table

Funds Raised by Nonfmancial Sectors* (billons of Dollars)

\begin{tabular}{|c|c|c|c|c|}
\hline $\begin{array}{l}\text { Fised } \\
\text { Yeal }\end{array}$ & Tolat & 45 & Government & $\begin{array}{l}\text { Al olver } \\
\text { Nonfnoriol }\end{array}$ \\
\hline 1965 & $\$ 71,2$ & & 30 & 867.5 \\
\hline 1966 & 760 & & 16 & 744 \\
\hline 1967 & 60 & & $n$ & 591 \\
\hline 1968 & 970 & & $20 \%$ & 76, \\
\hline 1969 & 967 & & 0.4 & 971 \\
\hline 910 & 936 & & 30 & 898 \\
\hline 1971 & 2,4 & & 19, & 105, \\
\hline 1972 & 161 & & 104 & 421 \\
\hline 1973 & 2021 & & 190 & 1826 \\
\hline 1974 & 1915 & & 3 & 1,0, \\
\hline 1975 & 1033 & & $501 \%$ & 132,6 \\
\hline 1976 & 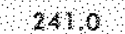 & & 820 & 50,2 \\
\hline
\end{tabular}

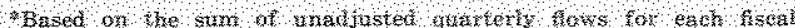

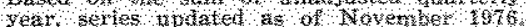

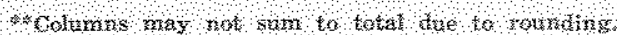

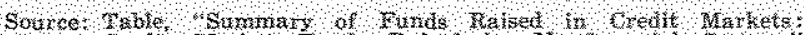

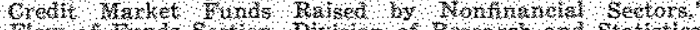

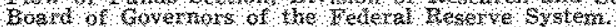


The decrease in the private demand for credit can be attributed in a general way to the decline in the level of economic activity between late 1973 and early 1975, during which time the United States experienced its most severe postwar recession. However, the specific factors affecting the demand for credit, as well as the supply of credit, are more complex.

The last recession was preceded by a number of shocks to the economy: the oil embargo and subsequent large increase in the price of energy; the end of wage and price controls; crop failures; and the introduction of new Government regulations regarding pollution and safety. These factors all combined to effect a one-time increase in the price level and a reduction in the country's productive capacity. ${ }^{9}$

The increase in the price level was first perceived as an increase in the rate of inflation, and led to upward revisions in lenders' and borrowers' expected rates of inflation, at least in the short tern. As a result, the supply of credit decreased and the demand for credit increased, and market interest rates rose rapidly in fiscal 1974. However, without any further shocks to the price level, the rate of change of prices retumed to its previous pace. As lenders and borrowers realized this, their infiationary expectations were revised downward. This resulted in a decline in the demand for credit and an increase in the supply, leading to a decline in market rates of interest.

Furthermore, the possibility of future oil embargoes, new wage and price controls, and further substantial changes in Govenment regulations resulted in increased uncertainty about the future state of the economy and lowered business confidence concerning profitable productive opportunities. Consequently, producers became more cautious about committing themselves to new investment projects, and the demand for credit to finance such investment declined. This general uncertainty also led to a substantial increase in the supply of short-term credit as many economic units sought to build their "liquidity" as protection against future contingencies. Another factor which contributed to the decline in private demand for short-term credit in fiscal 1975 was the sharp decrease in inventory investment during the first half of 1975 , which tended to reduce short-tem private borrowing. ${ }^{10}$

In contrast to fiscal 1975, the total funds raised in fiscal 1976 by all nonfinancial sectors increased by

\footnotetext{
"See Denus S. Kamosky, "The Link Between Monty and Prices - 1971-76," this Review (The 1976), pp. 17-23.

nose Giber, "Bavk Financing," pp. $5+6$.
}

about $\$ 58$ billion. Since the 1976 budget deficit was larger than the 1975 deficit (Table 1), the Government demand for credit again increased. The Federal Government raised $\$ 82.8$ billion in fiscal 1976, an increase of about $\$ 32$ billion over the fiscal 1975 level of $\$ 50.7$ billion (see Table II). The funds raised by all other nonfinancial sectors also increased in fiscal 1976 , by $\$ 25.6$ billion over the fiscal 1975 level. Nevertheless, these private nonfinancial sectors raised almost $\$ 30$ billion less in fiscal 1976 than in fiscal 1974 .

Although the total funds raised by the private sector increased in fiscal 1976 , the private demand for credit did not show a substantial increase. In fact, private short-term credit declined during most of fiscal 1976. The sluggish private demand for credit during fiscal 1976 showed up in the decline of business loan demand at commercial banks and the volume of commercial paper outstanding, both of which are primary sources of short-term credit by corporations. ${ }^{11}$ The voltme of commercial paper declined between March 1975 and May 1976, while business loans at commercial banks declined throughout fiscal 1976.

With an increase in the Government's demand for credit and little change in private demand, the total demand for credit increased. However, interest rates did not increase, as would be expected if the total demand for credit increased while the supply was constant. Instead, in fiscal 1976 interest rates were generally lower than in fiscal 1975. This combination of lower interest rates and higher credit indicates that the supply of credit increased both absolutely and relative to the total demand for credit.

The decrease in the rate of inflation since mid-1974 and the moderate rates of growth of the monetary base and the money stock during fiscai 1976 resulted in downward revisions of investors expected rates of inflation. This tended to increase the supply of credit since lenders did not have to require as high an interest rate to maintain their purchasing power. In addition, the amount of funds avalable for lending increased during fiscal 1976, as indicated by an almost 19 percent increase in gross private saving over this period.12

The distribution of credit between the Government and private sectors has changed considerably in the last two fiscal years. In fiscal $1975,27.7$ percent of all

\footnotetext{
tibid, p. 4.

12Gross private saving includes personal saving ad uxdistributed comporate profits (with inventory vamation and capisal consumption adjustments).
} 


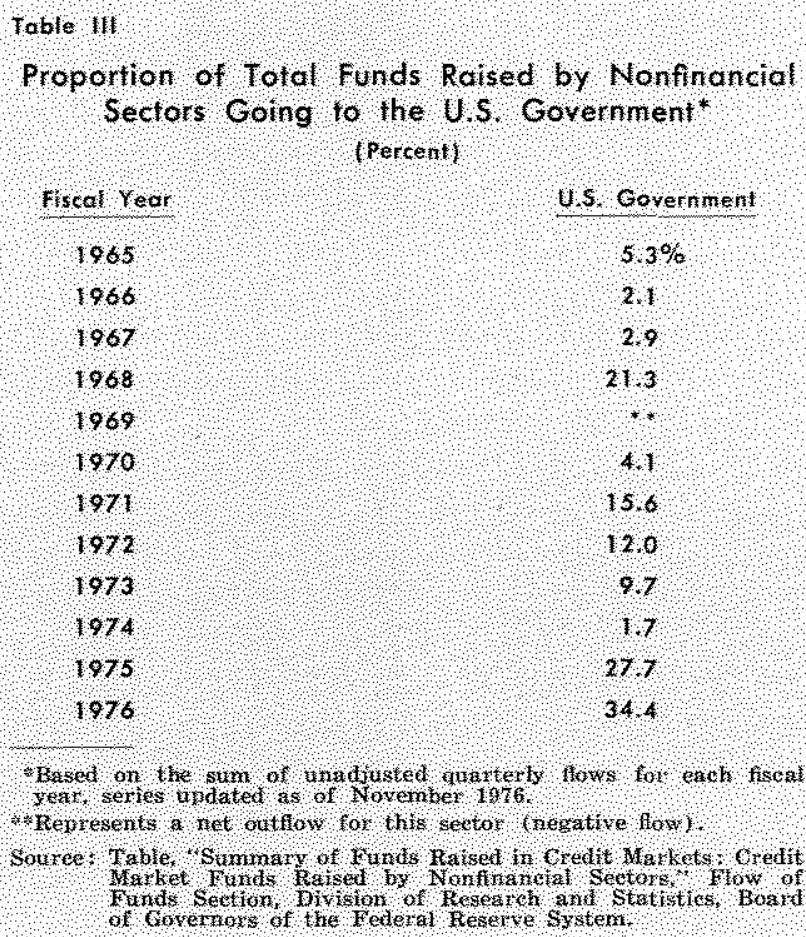

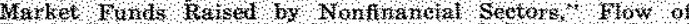

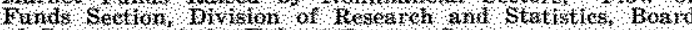
of Cibnerans of the Federat hesente systen.

funds raised in the credit markets by nonfinancial sectors went to the U.S. Government, up from 1.7 percent in fiscal 1974 (see Table III). The Government's share of funds increased further in fiscal 1976 , to 34.4 percent.

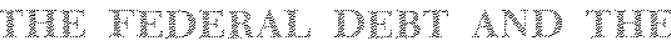 WDERA}

As shown in Panel 3 of Chart III, the proportion of the total outstanding Federal debt (total gross public debt less debt held by U.S. Government agencies and trust funds) held by the Federal Reserve had been rising fairly steadily through $1974-$ from about 12 percent in 1962 to almost 24 percent in fiscal 1974. In the ten fiscal years prior to fiscal 1975 , the largest increase in the Federal debt was recorded in fiscal $1968, \$ 20.7$ billion, of which 26.6 percent was monetized." From fiscal 1970 through fiscal 1974, the Federal Reserve generally monetized over 20 percent of the increases in the Federal debt (see Table IV). Many analysts expected this pattern to continue through fiscal 1975 and 1976, but instead the Federal Reserve monetized much lower proportions of the increases in the debt.

13The Federal Reserve does not purchase Government securi ties directly from the Treasury when engaging in open market operations. Rather, it purchases securities which the Treasury has already sold to the private sector.

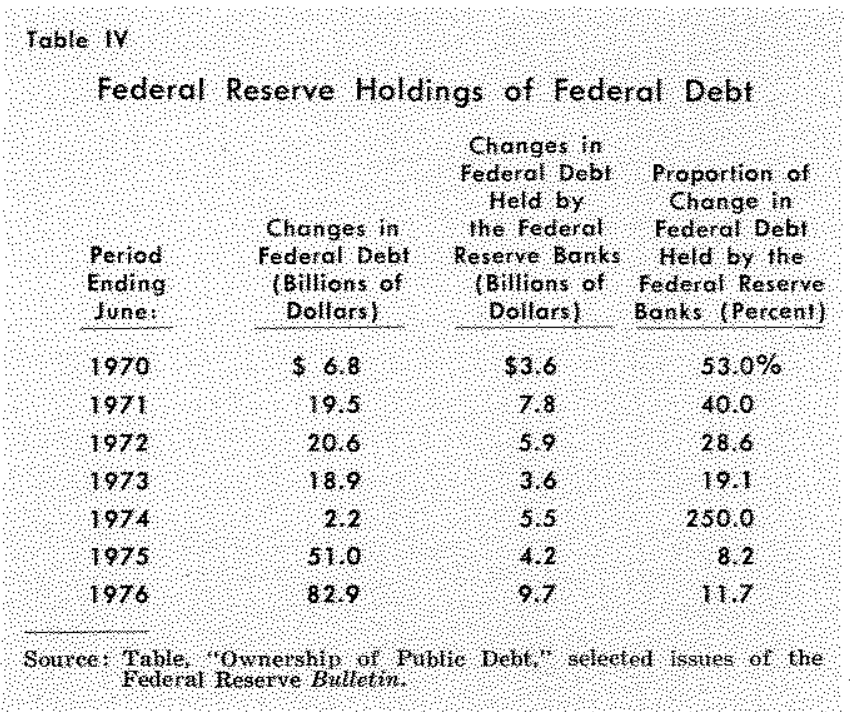

To finance the 1975 deficit, Federal debt increased $\$ 51$ billion. ${ }^{14}$ During fiscal 1975, the Federal Reserve increased its holdings of the outstanding debt by $\$ 4.2$ billion, so that 8.2 percent of the increase in the debt was monetized (see Table IV). In fiscal 1976, 11.7 percent of the $\$ 82.9$ billion increase in the debt was monetized. Consequently, there was not a large increase in the growth of the monetary base, and the expected surge in the money stock did not materialize (see panels 4 and 5 of Chart III). While the proportion of the total outstanding Federal debt held by the Federal Reserve decreased, a larger proportion was being taken by commercial banks, corporations, and "other investors"15 (see Tables V and VI).

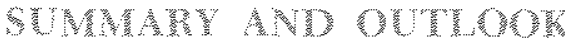

Of the total funds raised in the credit markets in fiscal 1975 and 1976, a larger proportion went to the Government than in the previous ten years (Table III). In fiscal 1975, the private demand for funds decreased; the private sector wanted to borrow less at any level of interest rates. Thus, their share of the total funds raised would have declined even if the Government's demand for funds had remained constant. On the other hand, had the Government demand for funds not increased, the decreased demand by private borrowers would have resulted in even lower interest rates.

\footnotetext{
1. Federal debt is not equal to the budget deficit mainly because of: 1) changes in the deficits of of -budget agencies, and 2) changes in cash and monetary assets of the Treasury.

" "Other investors" include savings and loan associations, nonprofit institutions, corporate pension trust funds, dealers and brokers, and certain Covernment deposit accounts and Govermment-sponsored agencies.
} 


\section{Influence of Federal Government Debt on Monetary Expansion}

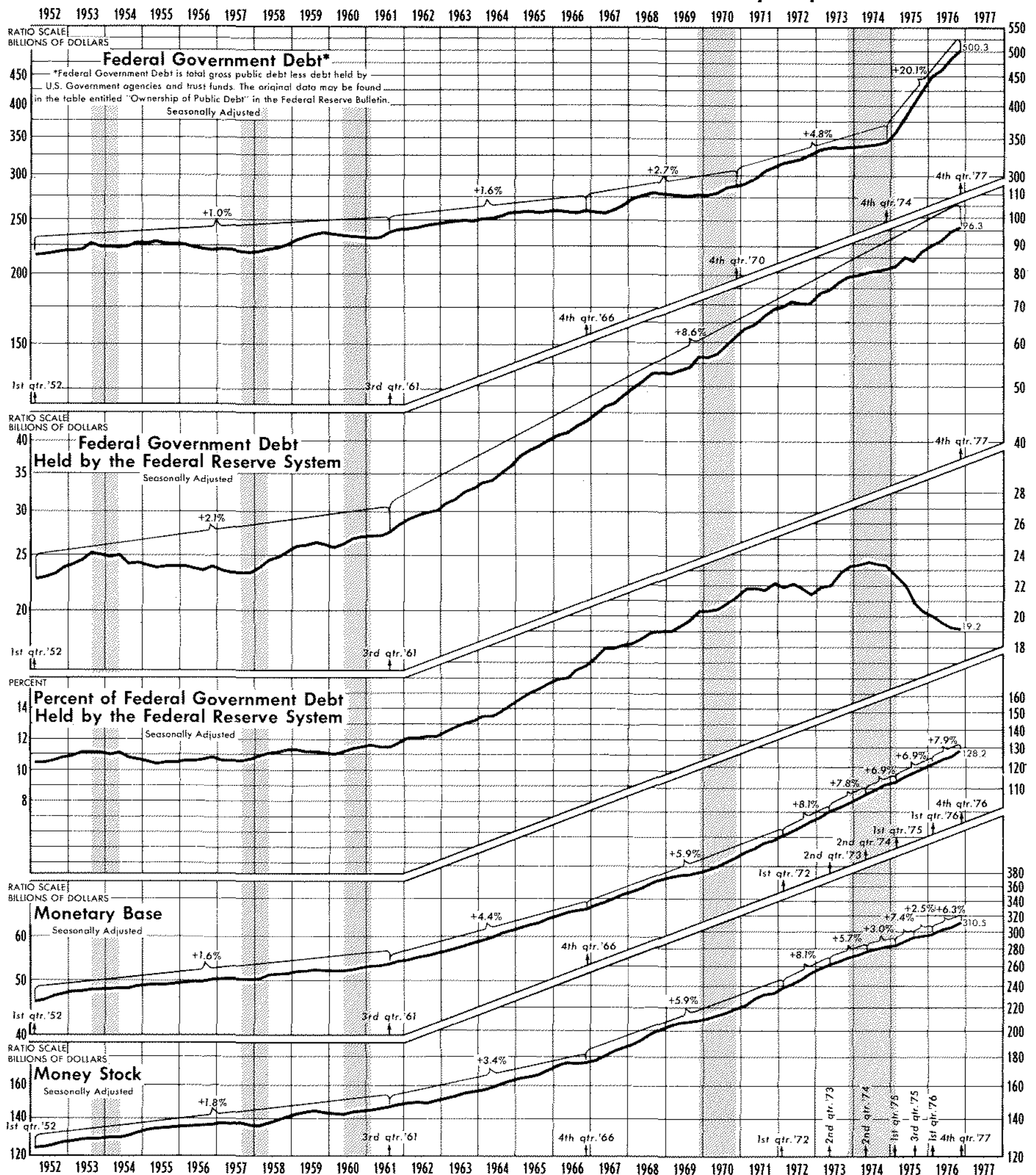

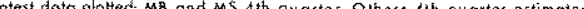




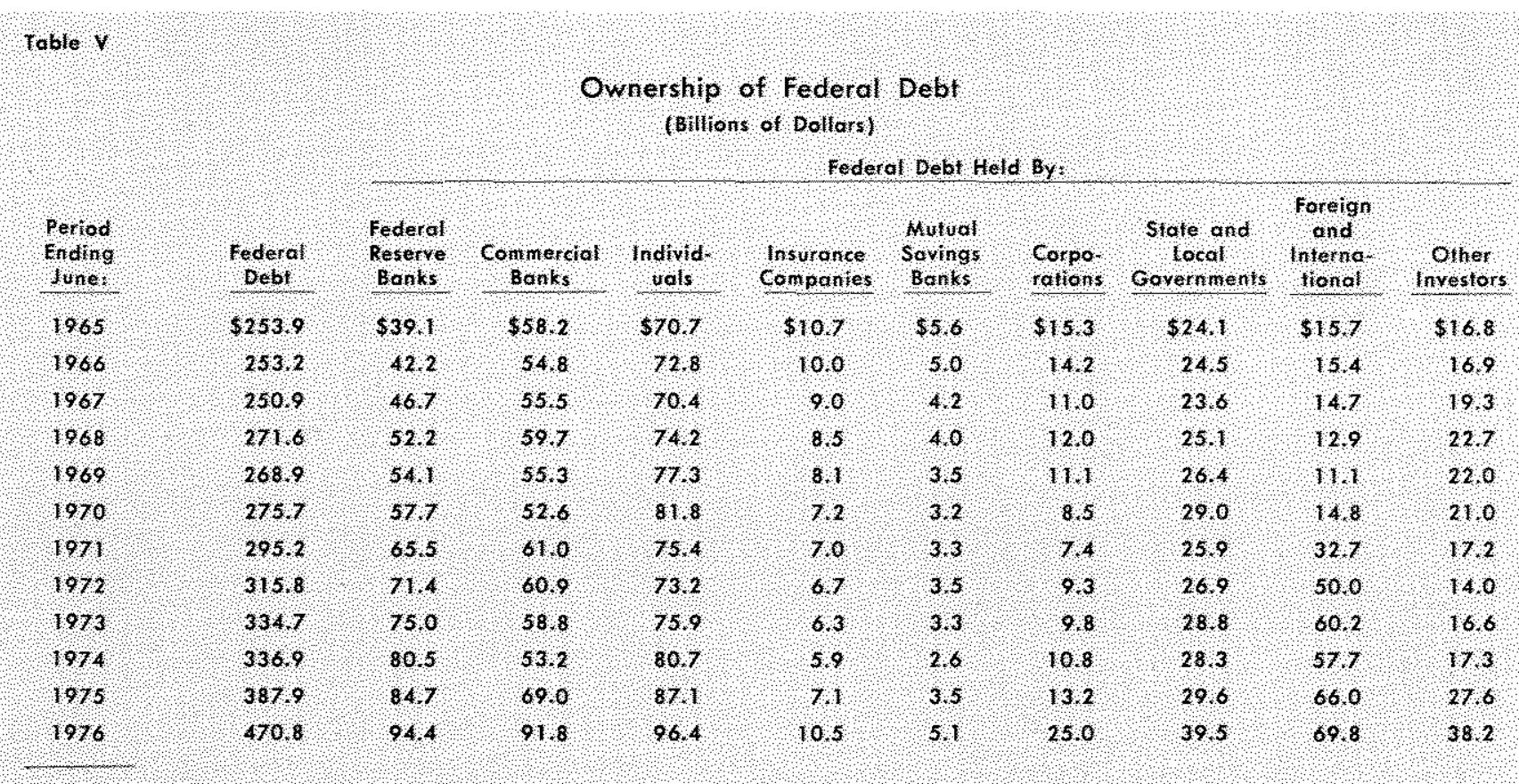

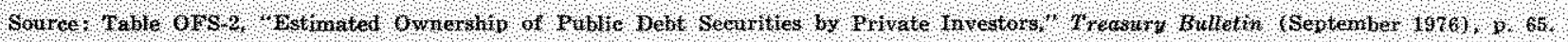

In fiscal 1976, the supply of credit increased relative to demand, so that the increased budget deficit again did not have the adverse effects on interest rates and private borrowing which had been expected by some analysts. As a result of the large decline in the private demand for credit in fiscal 1975 and the increased supply of credit in fiscal 1976, upward pressure on interest rates did not materialize.
The Federal Reserve did not purchase a large proportion of the debt in fiscal 1975 and 1976, compared to the previous five fiscal years. In fact, the Federal Reserve's share of the total outstanding debt declined in the last two fiscal years. The Government deficit was mainly financed by the private sector, with larger proportions of the debt held by commercial banks, corporations, and some nonbank financial institutions.

\section{Toble VI}

Percentage Ownership of rederal Debl

\begin{tabular}{|c|c|c|c|c|c|c|c|c|c|}
\hline $\begin{array}{l}\text { Berod } \\
\text { Endins? }\end{array}$ & $\begin{array}{l}\text { Rederal } \\
\text { Reserve } \\
\text { Bankis }\end{array}$ & $\begin{array}{c}\text { Commerciol } \\
\text { Banks }\end{array}$ & ndolviduols & $\begin{array}{l}\text { nsuronce } \\
\text { Componies }\end{array}$ & $\begin{array}{l}\text { Mutual } \\
\text { Sarings: } \\
\text { Bonks }\end{array}$ & Corporolions & $\begin{array}{l}\text { Stafe and } \\
\text { Local } \\
\text { Governments }\end{array}$ & $\begin{array}{l}\text { Horedgn } \\
\text { nnd } \\
\text { nennond }\end{array}$ & $\begin{array}{l}\text { Otfer } \\
\text { Investors }\end{array}$ \\
\hline 1865 & 15,48 & $22,9 \%$ & $278 \%$ & $42 \%$ & $22 \%$ & $60 \%$ & $95 \%$ & $62 \%$ & $66 \%$ \\
\hline 1966 & 16.6 & 216 & 28,8 & 39 & 20 & 5.6 & 97 & 61 & 67 \\
\hline 1967 & 18.6 & 221 & 281 & 30 & 17 & 44 & 94 & 59 & 71 \\
\hline 1968 & 19.2 & 220 & 273 & 31 & 18 & 44 & 92 & 47 & 84 \\
\hline 1909 & 201 & 200 & 287 & 3.0 & 13 & 4 & 9. & 4 & 8,2 \\
\hline 1970 & 209 & 191 & 297 & 26 & 12 & 31 & 10,5 & 54 & 70 \\
\hline 1971 & 22, & 207 & 25,5 & 2.4 & 11 & 2,5 & 8.8 & 111 & 58 \\
\hline 1972 & 22.6 & 193 & 232 & 21 & 11 & 29 & 8,5 & 15.8 & 44 \\
\hline 1973 & 22,4 & 176 & 227 & 19 & 10 & 28 & 8.6 & 180 & 50 \\
\hline 1974 & 209 & 150 & 240 & 18 & 08 & 32 & 84 & 171 & 51 \\
\hline 1975 & 21.8 & 178 & 22.5 & 18 & 0, & 34 & 76 & 170 & 71 \\
\hline 1970 & 20.0 & 195 & 20.5 & 22 & 11 & 53 & 8,4 & 148 & 81 \\
\hline
\end{tabular}

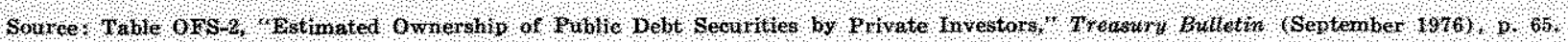


The negligible impact of the 1975-76 Federal deficits on credit markets suggests that these deficits were primarily due to passive rather than active elements in the budget. Thus, increased Government borrowing due to the decline in economic activity tended to be offset by a concomitant reduction in private borrowing. For example, it has been estimated that two-thirds of the budget deficit during this period was due to passive elements. ${ }^{16}$

Large budget deficits such as those experienced in 1975 and 1976 will continte to be a matter of concern for the next few years. The projected deficit for fiscal 1977 is $\$ 57.2$ billion, somewhat lower than the fiscal 1976 deficit, and this is before any new tax cuts or spending programs which the new Administration may propose to include in this year's budget. With a

16Carlson, "Large Federal Budget Deficits," p. 6.
\$12-16 billion program like that recently proposed by the new Administration for fiscal 1977, the current budget deficit will probably be larger than the $\$ 65.6$ billion fiscal 1976 deficit.

If the private demand for credit remains sluggish in 1977, as was the case during most of 1976, then there will be little upward pressure on interest rates as a result of the large amount of Govermment borrowing required to finance the 1977 deficit. On the other hand, if private borrowing increases rapidly in 1977 , the large amount of Government borrowing will contribute to strong upward pressure on interest rates. Without a matching increase in the supply of credit, such an increased demand will increase interest rates. Under these circumstances, the large Government deficit could lead to the crowding-out effects which some feared would occur in 1975-76. 